\title{
WATERMELON FERTIGATION WITH ELECTRICAL CONDUCTIVITY AND PH MONITORING IN THE SOIL SOLUTION
}

Doi:http://dx.doi.org/10.1590/1809-4430-Eng.Agric.v36n4p 622-630/2016

\section{MANOEL J. DA SILVA JÚNIOR ${ }^{1}$, PAULA C. VIANA ${ }^{2 *}$, JOSÉ F. DE MEDEIROS ${ }^{1}$, JOÃO G. A. LIMA ${ }^{2}$, ANA J. DE O. TARGINO ${ }^{1}$}

\begin{abstract}
In the olericulture, in general, is practiced intensive fertilization, which creates a risk of salinization and change of high $\mathrm{pH}$, which if not well monitored can cause production losses, excessive spending on fertilizers and environmental contamination. We developed this study with the aim of controlling fertigation on watermelon through the behavior of the electrical conductivity (EC) and $\mathrm{pH}$ in the soil solution obtained through porous ceramic cups extractors. The $\mathrm{EC}$ and $\mathrm{pH}$ values were corrected by the current soil moisture for the moisture field capacity, due to different moisture values at the time of extraction. The monitoring comprised 19 assessments d uring 80 days of cultivation. We can control the $\mathrm{pH}$ and $\mathrm{EC}$ of the soil and maintain them at optimal levels for the crop through real-time monitoring of the soil solution. The monitoring enabled the achievement of a balanced fertigation.
\end{abstract}

KEYWORDS: Citrullus lanatus, fertilization, solution extractors, salinity.

\section{INTRODUCTION}

The fertigation is very advantageous for farmers because it enables to reduce the cost of fertilizer application, to save labor and the use of agricultural machines. Also, by splitting into a larger number of plots the total dose of fertilizer, reducing losses and improving the services to the plants needs in different stages of crop development, improving the fertilizers efficiency and allowing to maximize the crop yield potential (FELTRIM, 2010). The nutrient implementation strategy through irrigation water has increasingly attracted farmers to exploit its use; however it is necessary to accurately quantify the nutrients absorbed by the plant and to monitor them from the soil solution, thus preventing nutritional imbalances, waste of fertilizers by leaching and volatilization, or often by salinization and soil acidification.

The watermelon is one of the main olericulture species in Brazil, especially in the Northeast, where climate conditions favorable to its cultivation and it can be planted all year round under irrigation (COSTA et al., 2013). Although it can be grown in various types of soils, the ones of sandy-clayey, deep and well-structured are the most suitable in relation to soil $\mathrm{pH}$; the watermelon develops well in $\mathrm{pH}\left(\mathrm{H}_{2} \mathrm{O}\right)$ of 5.0 to 6.8 .

The soil solution is the term that refers to water that occupies the pore space of the soil and in it the ions that are in hydrated form are dissolved; only a small amount of soil chemical elements is in the solution, most of them are in the solid phase, mainly in clayey soils; the plants absorb nutrients from the soil solution. According to SOUZA et al. (2013), the composition knowledge of the liquid phase, commonly called the soil solution, is very important for monitoring the nutrients availability for plants, environmental contamination processes and those related to the understanding of the characterization dynamics and soils evaluation affected by salt.

The determination of the electrical conductivity of the saturation extract (ECse) is more common in the literature than the EC measured obtained by other methodologies, however a method has been highlighted for the ions monitoring in the soil solution, it is the soil solution extraction through porous ceramic cups (OLIVEIRA et al., 2011; MARQUES et al., 2012), this method allows to monitor the EC behavior in solution, besides that it is a non-destructive method

\footnotetext{
${ }^{1}$ UFERSA/M ossoró- RN, Brasil.

${ }^{2}$ UFRB/Cruz das Almas - BA, Brasil.

*Corresponding author. E-mail: paulinhatmgm@ hotmail.com

Received in: 11-11-2014

Accepted in: 3-22-2016
} 
compared to the saturation extract, enabling the liquid phase collection directly in the field, providing the collection repetition in the same place and for long periods.

The $\mathrm{pH}$ measures the $\mathrm{H}^{+}$ions concentration present in the soil solution, which is the active acidity present in the solution and immediately in contact with plant roots, is another quality indicator from the point of view of higher plants development. The $\mathrm{pH}$ influences the solubility, the concentration in solution and the ionic form of nutrients in the soil. CALLEGARI et al., (2011), monitoring the $\mathrm{pH}$ of the soil during two melon production cycles, noted that with the increase in the value of this parameter, the soluble solids content of the pulp and fruit weight reduced.

The intensive fertilization practiced in olericulture in general and especially in the fertigated cucurbits, generates a risk of salinization and variation of high $\mathrm{pH}$, which if they are not well monitored can cause yield loss, excessive expenditures with fertilizers and environmental contamination, both in the eutrophication of water resources and soil degradation. Thus, the monitoring of these variables during the production cycle can help to maintain a good nutritional balance, but without risks to the environment.

At the foregoing, we aimed to develop a guidance technique for fertigation on watermelon through the monitoring of EC behavior and the $\mathrm{pH}$ in the soil solution through porous ceramic cups extractors over the crop cycle.

\section{MATERIAL AND METHODS}

The study was carried out, from February to May 2013, in a greenhouse, in the Federal Rural University of Semi-arid (UFERSA), the city of Mossoro, State of Rio Grande do Norte, whose geographical coordinates are $5^{\circ} 12^{\prime} 03^{\prime \prime}$ South latitude and $37^{\circ} 19^{\prime} 37^{\prime \prime}$ West longitude and altitude of $12 \mathrm{~m}$. The climate, according to Köppen, is dry and hot, with two seasons: a drought that usually happens from June to January and a rainy season from February to May; It has an average annual temperature of $27^{\circ} \mathrm{C}$, irre gular annual rainfall with a verage of $673 \mathrm{~mm}$.

The soil used in the experiment was collected in a property in the municipality of Baraúna$\mathrm{RN}$, and is the Eutrophic Cambisol with clayey texture type. To characterize it we removed a composite sample, which was chemically analyzed in the Soil, Water and Plant Analysis Laboratory (LASAP) of UFERSA. The soil characteristics are shown in Tables 1 and 2, according to the recommend methodology by EMBRAPA (1997).

The water used for irrigation was from a pit that belongs to the Company of Water and Sewers of Rio Grande do Norte (CAERN), located at the Federal Rural University of the Semi-arid, which supplies the university and surrounding neighborhoods. The chemical characteristics of the water are shown in Table 3. The chemical analysis of the water was carried out at the Irrigation and Salinity Laboratory of the Department of Environmental Sciences and Technology of UFERSA, according to methodology recommended by EMBRAPA (1997).

TABLE 1. Chemical characteristics of the soil used in the experiment.

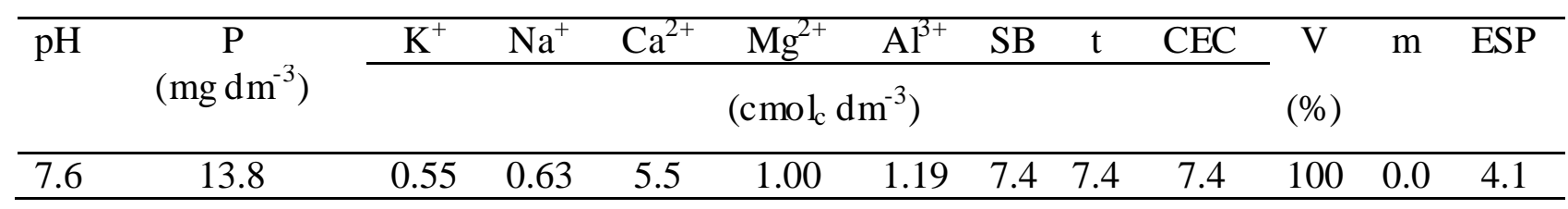

TABLE 2. Physical characteristics of the soil used in the experiment.

\begin{tabular}{cccccc}
\hline \multirow{2}{*}{ Depth $(\mathrm{cm})$} & \multirow{2}{*}{ Clayey } & \multirow{2}{*}{ Silt } & \multicolumn{3}{c}{ Sand } \\
\cline { 4 - 6 } & & & Total & Thick & Thin \\
\hline & 34 & 8 & 58 & 38 & 20 \\
\hline $0-20$ & 34 & & & 38 & \\
\hline
\end{tabular}


TABLE 3. Result of the chemical analys is of the water used in the experiment irrigation, MossoróRN, UFERS A, 2013.

\begin{tabular}{|c|c|c|c|c|c|c|c|c|c|}
\hline Water origin & $\mathrm{pH}$ & $\begin{array}{c}\mathrm{ECw} \\
\left(\mathrm{dS} \mathrm{m}^{-1}\right)\end{array}$ & Ions $(\mathrm{mn}$ & $\mathrm{ol}_{\mathrm{c}} \mathrm{L}^{-1}$ & & Anior & $\mathrm{mol}_{\mathrm{c}} \mathrm{I}$ & & SAR \\
\hline Sandstone & 8.0 & 0.50 & $\begin{array}{cc}\mathrm{Ca} & \mathrm{Mg} \\
2.00 & 0.90\end{array}$ & $\frac{\mathrm{Na}}{2.87}$ & $\begin{array}{c}\mathrm{K} \\
0.4\end{array}$ & $\frac{\mathrm{HCO}_{3}}{4.0}$ & $\frac{\mathrm{CO}_{3}}{0.2}$ & $\begin{array}{l}\mathrm{Cl} \\
1.8\end{array}$ & 2.32 \\
\hline
\end{tabular}

The amounts of fertilizers applied corresponded to 5 levels of nitrogen-nitrate concentration $\left(\mathrm{N}^{-} \mathrm{NO}_{3}^{-}\right)$and five levels of potassium concentration $\left(\mathrm{K}^{+}\right)$on the soil solution, defined as follows: C1 (0, 0); C2 (0, 120); C3 (0, 240); C4 (165, 60); C5 (165, 180); C6 (330, 0); C7(330, 120); C8 (330, 240); C9 (495, 60); C10 (495,180); C11 (660,0); C12 (660, 120); C13 (660, 240) mg.L.' of $\mathrm{N}-N O_{-3}$ and $\mathrm{K}^{+}$respectively. The zero level was considered as the value of the $\mathrm{N}_{-} \mathrm{NO}_{-3}$ and $\mathrm{K}^{+}$ concentration found in the soil solution in natural conditions and the other concentration levels were supplied through the fertilization applied via fertigation.

The fertigations were carried out manually at intervals of 3 to 4 days according to the analysis of the soil solution obtained by the use of solution extractors. The volume of fertilized solution applied in each fertigation event was calculated to be enough to raise the current soil moisture to the field capacity moisture. We used as fertilizers the following products: calcium nitrate, potassium chloride, monobasic phosphate of potassium, potassium nitrate, nitric acid, calcium chloride, magnesium sulphate and phosphoric acid as a source of macronutrients and copper sulphate, sodium molybdite, boric acid, zinc sulphate, and iron EDTA as micronutrients sources. However, the use of one source or another depended first, of the dose to be applied at the time of fertigation and second, of the electric conductivity and $\mathrm{pH}$ of the soil solution at the same time.

The porous ceramic cups extractors were installed at a distance of $0.10 \mathrm{~m}$ from the watermelon, at a depth of $0.15 \mathrm{~m}$. With equivalent distance and depth, tensiometers were inserted into the soil with the intention of checking indirectly the soil water potential at the extraction moment. Knowing the soil moisture at the time of the extraction enables to estimate the $\mathrm{pH}$ and EC on standard or predetermined moisture. The water retention curve in the soil (Figure 1) was constructed representing a real condition of irrigation and evaporation in the greenhouse.

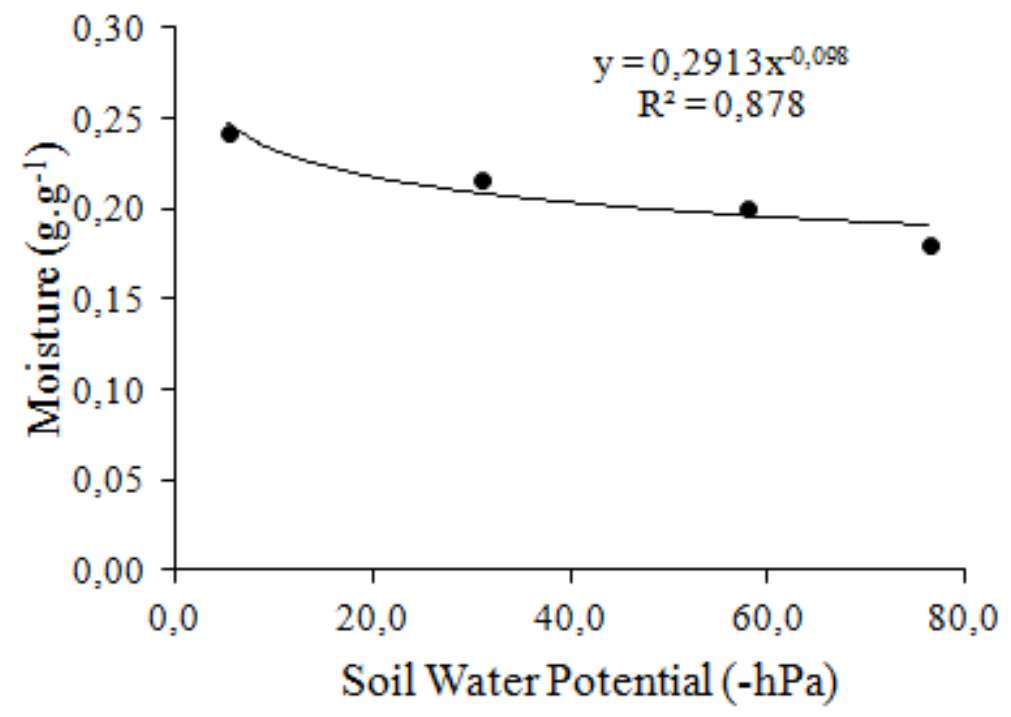

FIGURE 1. Water retention curve in the soil.

The procedure was carried out putting the soil in five vases in the greenhouse, with puncture tensiometers installed at $0.15 \mathrm{~m}$ of depth; the moisture was obtained by the gravimetric method. We used a spaghetti type emitter to slowly saturate the soil and after the free drainage the water supply was cut. After the soil stopped draining, the moisture and soil water potential measures started for 
about fifteen days, at which we observed low moisture in the soil. The soil moisture data were plotted in charts in function of the measured tension and potential equations were adjusted to be used in the calculation of soil moisture and irrigation management.

The soil solution extractors consisted of a PVC pipe, attached to a porous ceramic cup in its lower end and the top sealed with special silicone rubber. A vacuum of about $80 \mathrm{kPa}$ was applied, about 14 hours before the solution collection. The removal of the solution from the extractors was done with a syringe connected to a nylon hose. Then the samples were stored, identified and transported to the laboratory, where $\mathrm{EC}$ and $\mathrm{pH}$ readings were carried out.

The $\mathrm{EC}$ and $\mathrm{pH}$ were monitored during the nutrients application period through fertigation, in 19 collections during the 80 days of cultivation. At each collection, the EC analysis were done with a calibrated conductivity meter with standard reference solution that has a specific conductance of $1413 \mu \mathrm{S} \mathrm{cm}^{-1}$ at $25^{\circ} \mathrm{C}$ and $\mathrm{pH}$ by the calibrated $\mathrm{pH}$ meter with buffer solution of $\mathrm{pH} 7.0$ and 4.0. The obtained $\mathrm{EC}$ and $\mathrm{pH}$ values were corrected through the current soil moisture for the field capacity moisture, according to the equations 01 and 02 . Every time that we observed that the $\mathrm{pH}$ or EC showed an increase trend, we sought to use in fertigation a nutrient source that could reduce the values in order to keep them with minimal variation and in the best possible range for the crop, using the equations:

$$
p H c o r r=p H \cdot \frac{M c}{M f c}
$$

that,

$\mathrm{pH}$ corr - corrected $\mathrm{pH}$;

$\mathrm{pH}-\mathrm{pH}$ in the soil solution obtained through extractors;

Mc - current soil moisture (\%),

Mfc - field capacity moisture (\%);

$$
\text { ECcorr }=E C \cdot \frac{M c}{M f c}
$$

where,

ECcorr - corrected electrical conductivity;

EC - electrical conductivity in the soil solution obtained by extractors;

Mc - current soil moisture (\%),

Mfc - field capacity moisture (\%);

\section{RESULTS AND DISCUSSION}

We observed in Figure 2A that the $\mathrm{pH}$ ranged during the cycle, varying between 4.0 and 7.0, and showing two different behaviors, one at the beginning of the cycle up to 51 days (Figure $2 \mathrm{~B}$ ) and the other from 51 to the 80 days of transplanting (Figure 2C). 

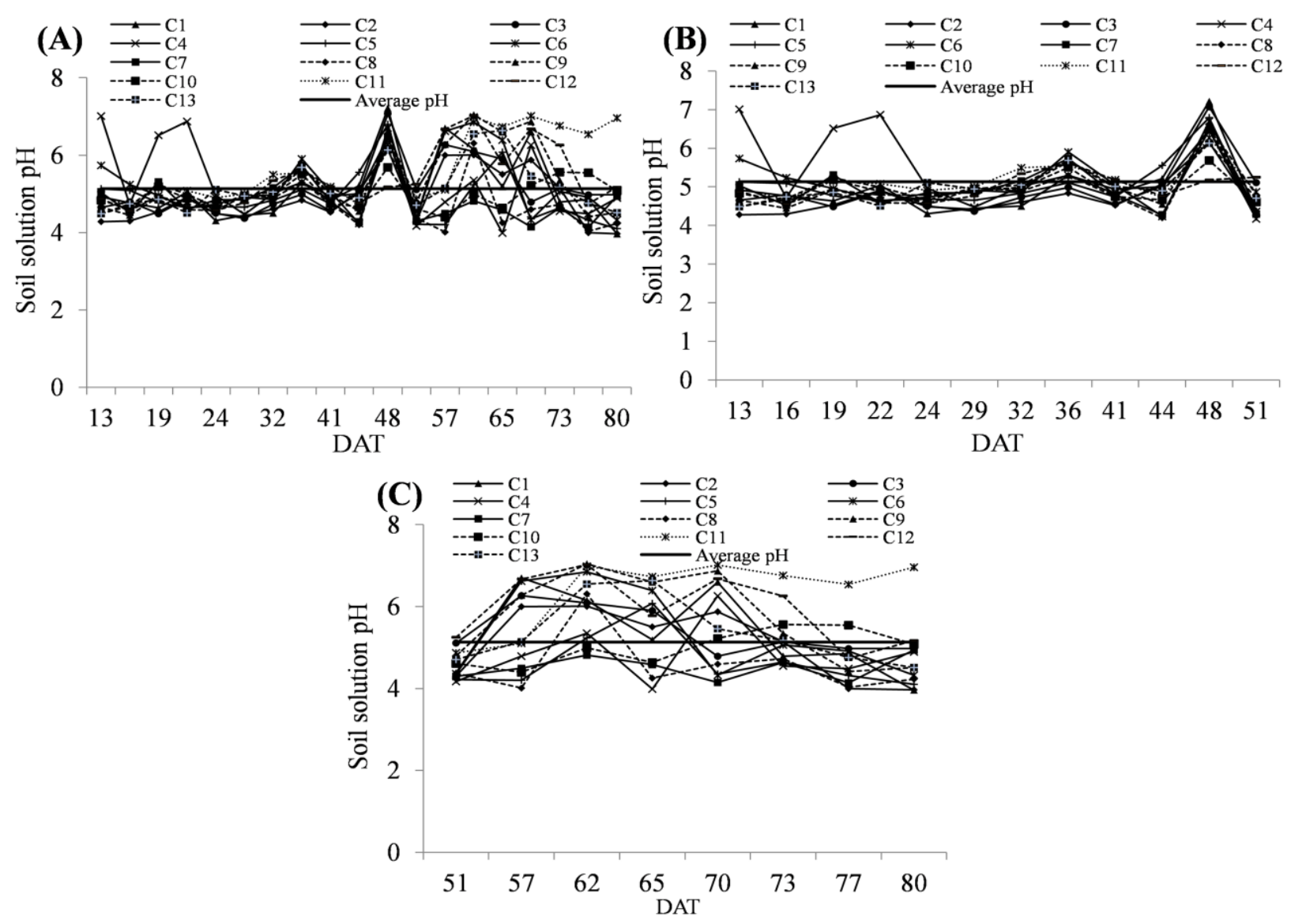

FIGURE 2. $\mathrm{pH}$ values in the soil solution, obtained through porous ceramic cups extractors during the watermelon cycle, accumulated depending on the days after the sowing. (A) - The whole period; (B) - $\mathrm{pH}$ behavior in the soil solution up to the $51 \mathrm{DAT}$; (C) $-\mathrm{pH}$ behavior in the soil solution from 51 up to 80 DAT.

In the first part of the cycle, the $\mathrm{pH}$ showed little variation in relation to the applied fertilizers concentrations, presenting to be homogeneous (Figure 2B). The soil buffering capacity in response to the applied fertilizer may have sustained this homogeneity, however, after the 50 days, we observed a greater variation in the $\mathrm{pH}$ of the soil solution, probably there was the neutralization of the buffering agents, from which we can mention the carbonates. In this cultivation stage, further attention was necessary in the use of fertilizers to make possible to maintain the $\mathrm{pH}$ with a little variation.

The obtained average for all concentration levels of applied fertilizers was $\mathrm{pH}$ equal to 5.0, considering that the watermelon tolerates mildly acidic soils, and it grows better in those with $\mathrm{pH}$ between 5.0 and 6.8, the average value obtained in the experiment was between this intervals, however in the lower limit. SOUZA (2012), studying the effect of nitrogen applied by fertigation in hybrid Olympia and Leopard watermelon, found averages values above the ones found in this experiment with $\mathrm{pH}$ equal to 7.55 for a depth of $15 \mathrm{~cm}$.

The use of higher concentrations of urea, nitric acid and phosphoric acid fertilizers that because having high acid values: 71, 46 and 76, respectively, according to Table 4, must have contributed to maintain the $\mathrm{pH}$ in this average (5.0), therefore below the initial average value (8.0). However, we should also observe the methodology differences, since the thin soil air-dried solution (TSAD), according to the routine patterns of laboratories for $\mathrm{pH}$ determination, is less concentrated than the soil solution collected by solution extractors that may present, comparatively, $\mathrm{pH}$ values more acidic than that, although the $\mathrm{pH}$ studies in the soil solution should be developed since it represents the cultivation environment in which the plant is in contact at the collection time.

The nitrogen fertilizer application by fertigation can cause desirable effects on soil chemical properties, such as the increase of the nutrient content applied in the soil and its availability to the 
plant, and undesirable effects, such as a possible increase in soil acidity, decreasing the $\mathrm{pH}$ (MALAVOLTA et al., 1997).

TABLE 4. Total volume of the stock solution of each fertilizer $(1 \mathrm{M})$ applied to each vase during the experiment.

\begin{tabular}{|c|c|c|c|c|c|c|c|c|c|c|}
\hline \multirow{2}{*}{ CONC } & \multicolumn{10}{|c|}{ Fertilizer (mL of the stock solution per vase) } \\
\hline & $\mathrm{KNO}_{3}$ & $\mathrm{Ca}\left(\mathrm{NO}_{3}\right)_{2}$ & $\mathrm{MgSO}_{4}$ & KCI & $\mathbf{C a C l}_{2}$ & $\mathrm{HNO}_{3}$ & $\mathrm{H}_{2} \mathrm{PO}_{4}$ & Urea & MAP & $\mathrm{KH}_{2} \mathrm{PO}_{4}$ \\
\hline $\mathrm{C} 1$ & 0.0 & 0.0 & 165.3 & 0.0 & 661.2 & 0.0 & 165.3 & 0,0 & 0.0 & 0.0 \\
\hline $\mathrm{C} 2$ & 0.0 & 0.0 & 165.3 & 172.1 & 661.2 & 0.0 & 127.8 & 0,0 & 0.0 & 37.5 \\
\hline $\mathrm{C} 3$ & 0.0 & 0.0 & 165.3 & 2604.1 & 661.2 & 0.0 & 75.0 & 0,0 & 0.0 & 90.3 \\
\hline $\mathrm{C} 4$ & 0.0 & 405.5 & 165.3 & 0.0 & 255.8 & 10.4 & 37.5 & 402,4 & 127.8 & \\
\hline C5 & 645.3 & 390.0 & 165.3 & 1222.9 & 271.2 & 0.0 & 7.5 & 120,7 & 90.0 & 67.8 \\
\hline C6 & 0.0 & 511.2 & 165.3 & 0.0 & 150.0 & 78.1 & 15.0 & 1568,5 & 150.3 & 0 \\
\hline C7 & 483.5 & 601.2 & 165.3 & 10.7 & 60.0 & 123.0 & 15.0 & 1246,7 & 127.8 & 22.5 \\
\hline $\mathrm{C} 8$ & 1082.0 & 601.2 & 165.3 & 933.0 & 60.0 & 128.3 & 15.0 & 715,2 & 135.3 & 15.0 \\
\hline C9 & 0.0 & & & 0.0 & 60.0 & 2.4 & 15.0 & & 150.3 & \\
\hline C10 & 812.6 & 631.2 & 165.3 & 51.3 & 30.0 & 219.2 & 7.5 & 2149,9 & 150.3 & \\
\hline $\mathrm{C} 11$ & 0.0 & 661.2 & 165.3 & 0.0 & 0.0 & 671.0 & 7.5 & 4258,8 & 157.8 & 0. \\
\hline $\mathrm{C} 12$ & 267.6 & 631.2 & 165.3 & 0.0 & 30.0 & 844.1 & 7.5 & 3796,1 & 150.3 & 0. \\
\hline $\mathrm{C} 13$ & 1244.6 & 571.2 & 165.3 & 217.6 & 90.0 & 595.0 & 15.0 & 3135,9 & 127.8 & 22 \\
\hline
\end{tabular}

The ammonium and the urea amidic salts showed acid behavior, which occurs due to the ammonium ion nitrification, causing the release of hydrogen ions, which will reduce the soil $\mathrm{pH}$ (MELO, 1987). The phosphoric acid has been widely used in fertigation; beyond being a good source of phosphorus it reduces the water $\mathrm{pH}$, avoiding the precipitation of phosphorus by calcium (ZANINI et al., 2007). LEAL et al. (2007) using nitrogen fertilizer on star fruit orchards observed that the $\mathrm{pH}$ was the soil chemical property more influenced by the application of nitrogen fertilizer.

TEIXEIRA et al. (2001), studying the effect of nitrogen fertilization $(0,200,400$ and $800 \mathrm{~kg}$ $\mathrm{ha}^{-1}$ year $^{-1}$ of $\mathrm{N}$ ) in chemical changes of some chemical properties of soil cultivated with banana, after two cycles of cultivation, verified that the nitrogen fertilization caused significant decreases in soil pH.

Except for isolated cases observed in $\mathrm{C} 4$ concentration, at 44 days after transplanting, we observed that the applied fertilizer concentrations showed $\mathrm{pH}$ values above the average (5.0), especially the $\mathrm{C} 4$ concentration that reached $\mathrm{pH}$ values above 7.0 (Figure 2B). According to SILVA \& MENDONÇA (2007), the pH increase may be due to some processes in the soil, such as: reduction of the resulting $\mathrm{H}^{+}$activity; mineralization of nitrogen organic forms; denitrification and decarboxylation of organic acids and for this experiment the fertilization using alkalizing fertilizers (Table 4) may also have contributed to higher $\mathrm{pH}$ values, at certain times of the cultivation. However, the monitoring enabled the identification and the values correction even during the cycle, whenever the amount of fertilizer to be applied allowed the use of other sources, as can be seen in Figure 1B, at the 51 days of cultivation.

In Figure 2C, we observed that from the 51 days after the transplanting up to the cycle end, the $\mathrm{pH}$ remained most of the time above the average (5.0). The $\mathrm{pH}$ increase in the soil solution at the end of the watermelon cycle should have occurred due to the suspension of the nitric acid application by fertigation in the soil, where it was replaced by fertilizers sources of less acidic reaction, justifying the importance of monitoring the soil solution. According to MALAVOLTA (2006), variations in $\mathrm{pH}$ values directly or indirectly affect most of the nutrients and their availability to the plants. SOUZA et al. (2012) warned about the dangers of using acid fertilizers in tropical soils that can cause acidification.

The concentration $7\left(\mathrm{~N}=330\right.$ and $\left.\mathrm{K}=120 \mathrm{mg} \mathrm{L}^{-1}\right)$ was the only one that remained below the average with $\mathrm{pH}$ values ranging between 4.0 and 5.0 until the end of the cycle, this occurred due to the fact that this fertilizer concentration level has a higher demand for nitrogen sources, in which was applied big amounts of fertilizers of nitric sources, besides the phosphoric acid and urea (Table 4) and small amounts of calcium sources that assist in the $\mathrm{pH}$ raising. On the other hand, this 
reduction of the soil solution $\mathrm{pH}$ was not more accentuated due to the fact that the irrigation water used in this experiment had $8.0 \mathrm{pH}$ and also to the high $\mathrm{pH}$ of the soil at the beginning of the study (7.66), as well as the monitoring that made changes in the fertilizers sources to prevent greater variations.

The use of extractors for $\mathrm{pH}$ monitoring in the soil solution was quite accurate, acting efficiently on the $\mathrm{pH}$ levels behavior in the soil solution. SALOMÃO et al., (2012), SILVA et al. (2012) and SOUZA et al., (2012) also used soil solution extractors to monitor the $\mathrm{pH}$ in the soil solution, obtaining satisfactory results with the technique used.

Figure $3 \mathrm{~A}$ includes the $\mathrm{EC}$ variation in the soil solution over the 80 days after the transplanting, in which we observed a big oscillation over the cycle with values between 0.57 and $2.076 \mathrm{dS} \mathrm{m}^{-1}$. From the beginning of the cycle up to $45 \mathrm{DAT}$, the EC maintained between 0.57 and $1.5 \mathrm{dS} \mathrm{m}^{-1}$ except for the concentration $\mathrm{C} 4\left(\mathrm{~N}=165\right.$ and $\left.\mathrm{K}=60 \mathrm{mg} \mathrm{L}^{-1}\right)$ and $\mathrm{C} 12(\mathrm{~N}=660$ and $\mathrm{K}=120$ $\mathrm{mg} \mathrm{L}^{-1}$ ), which showed higher EC between 1.8 to $2.0 \mathrm{dS} \mathrm{m}^{-1}$ in this period. This probably occurred due to the nitrogen and potassium sources used show high levels of salinity and these concentrations received proportionally greater amounts of potentially salinization fertilizers due to the fertigation management adopted in the experiment, such as calcium chloride in $\mathrm{C} 4$ and urea in C12.
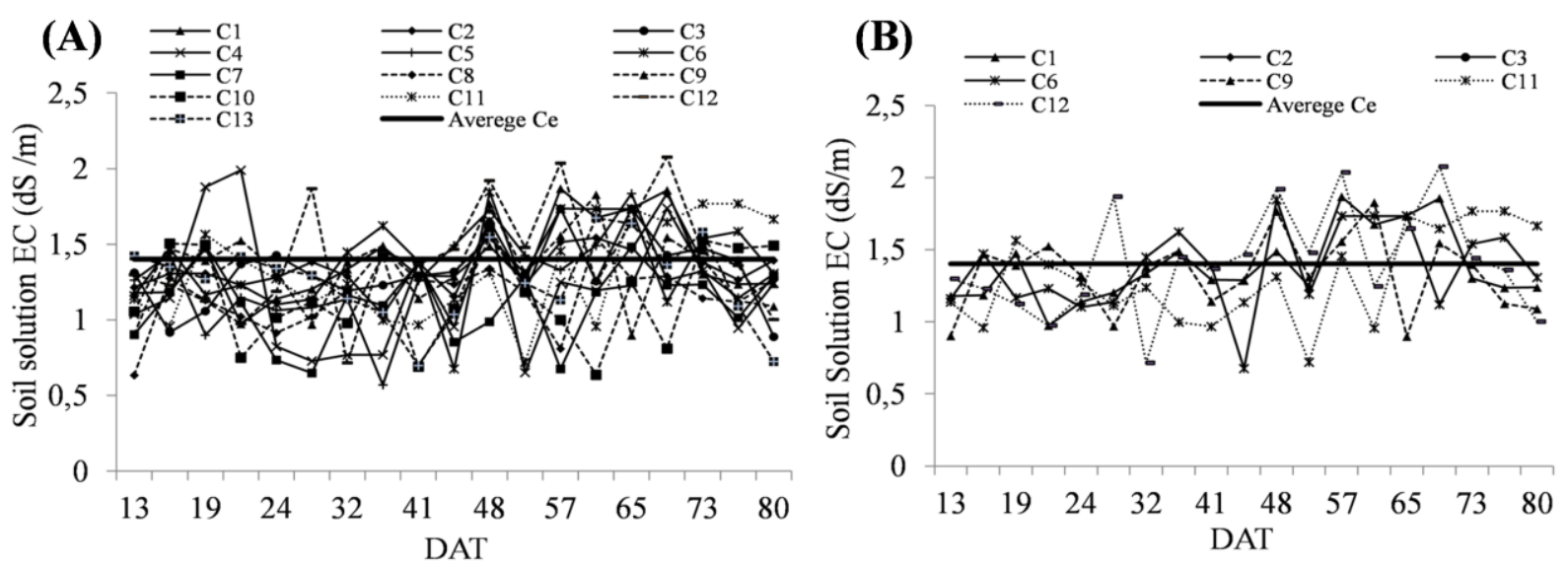

FIGURE 3. EC values in the soil solution, obtained through porous ceramic cups extractors during the watermelon cycle on the days after the transplanting (DAT). (A) - All concentrations; (B) - EC higher average values in the soil solution at $80 \mathrm{DAT}$.

The use of fertilizers tends to cause salinization in the soil, as observed by SOUZA et al. (2012) that the increase of the applied dose of these nitric fertilizers associated with the localized application can promote damage to plants by salinity, and also SILVA (2010) studying evapotranspiration and watermelon yield under different levels of nitrogen and irrigation water salinity, realized the increase of EC at 39 DAT.

The average obtained for the EC values during the 80 DAT was $1.28 \mathrm{dS} \mathrm{m}^{-1}$ and the small changes in the values found represent the attempt of EC maintenance within the limit range for the crop productivity maintenance, without dispensing the fertilizers application according to the defined concentration levels of fertilizer to be applied. We know that the watermelon crop tolerates an EC in the saturated soil paste of up to $2.2 \mathrm{dS} \mathrm{m}^{-1}$ for the no reduction in its production, and considering that the EC in the soil solution, extracted with solution extractors, is more concentrated than the EC of the saturated paste, the plant should tolerate higher values of EC in soil solution above $2.2 \mathrm{dS} \mathrm{m}^{-1}$.

The concentrations $\mathrm{C} 1, \mathrm{C} 2, \mathrm{C} 3, \mathrm{C} 6, \mathrm{C} 9, \mathrm{C} 11$ and $\mathrm{C} 12$ showed the highest $\mathrm{EC}$ average values in the soil solution, equal to $1.48,1.36,1.32,1.38,1.341 .31$ and $1.41 \mathrm{dS} \mathrm{m}^{-1}$, respectively (Figure $3 \mathrm{~B})$. The $\mathrm{C} 11$ and $\mathrm{C} 12$ showed higher values in the last days of the cycle, period in which occurred the greater application of nitrogen sources, mainly urea, whose results are confirmed when verified 
with the study of COSTA et al., (2009), that monitored the soil EC under fertigation with different concentrations of urea, verifying that soil solution showed higher concentration of dissolved salts in the soil upper layers with higher urea applications. However in such concentrations, the EC was still inside a range in which the plant tolerates in terms of salinity.

The EC is a variable widely used to evaluate probable salts risks in plant soil system. According to DIAS et al., (2005), with the assistance of porous ceramic cups extractors is possible to monitor the total concentration of salts in the soil solution and maintain the salinity in desired level. As for MARQUES et al., (2012), the extraction of the soil solution via extractors is faster and can be promptly obtained over time and in the same sample space without the need for soil sample collection. Thus, we verified that the $\mathrm{pH}$ and the $\mathrm{EC}$ monitoring of the soil solution with the use of porous ceramic cups extractors contributed to achieving a more environmentally equilibrated fertigation, aiming the soil potential use and the balance in the addition of fertilizers without, however, restricting the plant nutrition at various levels of fertigation with nitrogen and potas sium.

\section{CONCLUSIONS}

The soil $\mathrm{pH}$ and $\mathrm{EC}$ are possible to control and to maintain at great levels for the crop through real-time monitoring of the soil solution. The monitoring enabled to achieve a balanced fertigation allowing deciding for the use of fertilizers in a way to avoid waste and to help to establish the ideal less saline or less alkaline sources, according to the crop need, reducing the impacts on the soil and plant.

\section{REFERENCES}

CALLEGARI, R.A.; MORAIS, F.A.; MIRANDA, N.O.; GOES, G.B.; SILVA, R.M. Correlação entre qualidade e produtividade de frutos de meloeiro e o $\mathrm{pH}$ do solo. Revista Verde de Agroecologia e Desenvolvimento Sustentável, Patos, v.6, p. p. 08 - 12-p.12, 2011.

COSTA, A.R.F.C.; MEDEIROS, J.F.; PORTO FOILHO, F.Q.; SILVA, J.S.; COSTA, F.G.B.; FREITAS, D.C. Produção e qualidade de melancia cultivada com água de diferentes salinidades e doses de nitrogênio. Revista Brasileira de Engenharia Agrícola e Ambiental, Campina Grande, v.17, n.9, p.947-954, 2013.

COSTA, F.S.; COELHO, E.F; CARVALHO, G.C.; BARROS, D.L.; S ANT'ANA, J.A.V ; NASCIMENTO JUNIOR, A.L. . Condutividade elétrica do solo sob fertirrigação com diferentes concentrações de ureia e nitrato de potássio na bananeira Terra. In: CONGRESSO BRASILEIRO DE CIÊNCIA DO SOLO, 32, 2009, Fortaleza, Anais... Fortaleza: UFC, 2009.

DIAS, N.S.; DUARTE, S.N.; GHEYI, H.R.; MEDEIROS, J.F.; SOARES, T.M. Manejo da fertirrigação e controle da salinidade do solo sob ambiente protegido, utilizando-se de extratores de solução do solo. Revista Brasileira de Engenharia Agrícola e Ambiental, Campina Grande, v.9, n.4, p.496-504, 2005.

EMBRAPA - EMPRES A BRASILEIRA DE PESQUIS A AGROPECUÁRIA. Manual de métodos de análise de solo. Rio de Janeiro: CNPS, 1997. $212 \mathrm{f}$.

FELTRIM, A.L. Produtividade de melancia em função da adubação nitrogenada, potássica e população de plantas. 2010. 75 f. (Doutorado em Agronomia) - Faculdade de ciências Agrárias e Veterinárias, UNESP, Jaboticabal, 2010.

LEAL, R.M.; NATALE, W.; PRADO, R.M.; ZACCARO, R.P. Adubação nitrogenada na implantação e na formação de pomares de caramboleira. Pesquisa Agropecuá ria B rasileira, Brasília, v.42, n.8, p.1111-1119, ago. 2007.

MALAVOLTA, E. Manual de nutrição mineral de plantas. São Paulo: Ceres, 2006. 638p.

MALAVOLTA, E.; VITTI, G.C.; OLIVEIRA, S.A. Avaliação do estado nut ricional de plantas : princípios e aplicações. Piracicaba: Potafos, 1997. 308p. 
MARQUES, J.D. DE O.; LUIZÃO, F.J.; TEIXEIRA, W.G.; FERREIRA, S.J. Variações do carbono orgânico dissolvido e de atributos físicos do solo sob diferentes sistemas de uso da terra na Amazônia Central. Revista Brasileira de Ciência do Solo, Viçosa, MG, v.36, p.611-622, 2012.

MELO, F.A.F. Ureia fertilizante. Campinas: Fundação Cargill, 1987. 192p.

OLIVEIRA, F. DE A.; MEDEIROS, J.F. DE; DUARTE, S.N.; SILVA JÚNIOR, M.J. da.;

CAMPELO, C.M. Calibração de extratores providos de cápsula porosa para monitoramento da salinidade e da concentração de íons. Engenharia Agrícola, Jaboticabal, v.31, p.520-528, 2011.

SALOMÃO, L.C.; SOUZA de, T.R.; BÔAS, R.L.V.; ANDRADE de, T.F.;FORATTO, L.C.;

SANTOS, A.J.M. Posicionamento de extratores de cápsula porosa em solo arenoso na citricultura fertirrigada por gotejamento. Irriga, Botucatu, v. 17, n., p. 469 - 480, out. - dez. 2012.

SILVA, J. L. A.; SILVA JÚNIOR, M. J.; MEDEIROS, J. F.; BARBOSA, M. R.; GONÇALVES, F. M.; FREITAS JÚNIOR, F. G.; SOUZA, M. S.; VIANA, P. C. Desenvolvimento da melancieira fertirrigada com nitrogênio e potássio controlados pela solução do solo. In: CONGRESSO NACIONAL DE IRRIGAÇÃO E DRENAGEM, 22, 2012, Cascavel. Anais... Ilha Solteira: UNESP, 2012.

SILVA, J.S. Evapotranspiração e produção de melancia sob diferentes níveis de nitrogênio e da salinidade da água de irrigação. 2010. 92 f. (Mestrado em Irrigação e Drenagem) Universidade Federal Rural do Semiárido, Mossoró, 2010.

SILVA, I. R.; MENDONCA, E.S. Materia organica do solo. In: R.F. et. al. Ed. Fetilidade do solo. Viçosa: Sociedade Brasileira de Ciencia do Solo, 2007. p. 275-374.

SOUZA, E.R.; MELO, H.F.; ALMEIDA, B.G.; MELO, D.V.M.; Comparação de métodos de extração da solução do solo. Revista Brasileira de Engenharia Agrícola e Ambiental, Campina Grande, v. 17, n. 5, p. 510-517, 2013.

SOUZA, T. R.; BÔAS, R. L. V.; QUAGGIO, J. A.; SALOMÃO, C. S.; FORATTO, L. C. Dinâmica de nutrientes na solução do solo em pomar fertirrigado de citros. Revista de Pesquisa Agropecuá ria B rasileira, Brasília, v.47, n.6, p.846-854, jun., 2012.

SOUZA, M.S. Nitrogênio e fósforo aplicados via fe rtirrigação em melancia híbridos olímpia e leopard. 2012. 282 f. (Doutorado em Agronomia: Fitotecnia)- Universidade Federal Rural do Semiárido, Mossoró, 2012.

TEIXEIRA, L.A.J.; NATALE,W.; RUGGIERO, C. Alterações em alguns atributos químicos do solo decorrentes da irrigação e adubação nitrogenada e potássica em bananeira após dois ciclos de cultivo. Revista Brasileira de Fruticultura, Jaboticabal, v.23, n.3, p.684-689, 2001.

ZANINI, J. R.; BARRETO, A. K. G.; FORATTO, L. C.; NATALE, W. Distribuição de fósforo no bulbo molhado, aplicado via fertirrigação por gotejamento com ácido fosfórico. Engenharia Agrícola, Jaboticabal, v. 27, n. 1, p. 180-193, 2007. 